10.53116/pgaflr.2020.1.5

\title{
Disinformation as a Tool Aimed at Weakening Consolidated Democracies
}

\author{
Artur Kozłowski" - Klaudia Skelnik" \\ * Artur Kozłowski, PhD habil., Professor of Social Sciences, WSB University in Gdansk, Dean of \\ The Department of Economy and Management, Poland, email: akozlowski@wsb.gda.pl, ORCID: \\ https://orcid.org/0000-0002-5359-192X \\ ** Klaudia Skelnik, M.A. in Political Sciences, WSB University in Gdansk, Poland, email: kskelnik@ \\ wsb.gda.pl, ORCID: https://orcid.org/0000-0003-2771-3900
}

\begin{abstract}
This scholarly article indicates threats to the stability of political systems of consolidated democracies resulting from disinformation. The article presents threats resulting from the effects of disinformation in four areas: state, society, politics and law. The authors demonstrate the exposure of society to manipulative effects of fake news, which affects human emotions, reasoning and behaviour due to the use of created images of reality. It has been pointed out that fake news as a targeted manipulation tool, while aiming to achieve its goals, exploits the imperfections of the human mind. For this reason, the individual and thus the society need support to protect themselves from the manipulative threat coming from this phenomenon. Protection from fake news must be provided with the respect of freedom of expression, the values of society, the individuals' liberties as well as legal rights. Disinformation is not a new phenomenon in itself, but the development of the Internet and social media allows for an unprecedented scale of social manipulation. The article also indicates that disinformation is often directed at civil liberties and destabilises the principles of social life and citizens' trust in public institutions, authorities or the media, regardless of whether its source is third countries or it is "produced" internally. In a democratic state a citizen should be able to make informed decisions and independently assess whether the information encountered in the social media is true or false.
\end{abstract}

Keywords: destabilisation, fake news, consolidated democracy, information, disinformation

\section{Access to information as a determinant of modern democracies}

While defining the concept of information, it should be noted at the outset that the concept is only seemingly simple, in fact it is complex. There is a multitude of different approaches to information in the literature, representing various fields and disciplines of science. In addition to scientific theories, the term is also commonly used (Ziólkowski, 2007, p. 51), which has considerable significance in political sciences. It can be assumed that the particular concept of information refers to several intuitive understandings. Firstly, each piece of information is a message about something, and secondly, information is acquired by the individual through observation or other mental activities (Greniewski, 1967 , p. 51). In scientific terms, information is generally defined either in an objective context or is closer to a subjective context when it is defined in social sciences. It should be noted that information, depending on the content or the adopted reference system, can 
also be interpreted in a broader or narrower sense. Broadly speaking, information is understood as a content taken from the outside world in the process of our adaptation to it and the adaptation of our senses (Fischer \& Świerczyńska-Głownia, 2006, p. 9). In a narrow sense, information refers to the message obtained by humans through observation or mental action, subject to transmission in the sender (human) - recipient (human) system (Groniewska, 1990, p. 45). Babik (2008), in turn, emphasises the importance of the concept of qualitative and quantitative recognition of the characterised concept. In the first of these ranges, the author points to the existence of qualitative definitions focused not so much on measuring but on describing information. He refers to several most important concepts: according to Gregory Bateson from the PaloAlto, information conveyed to students during their education at school is one of the factors that shape people's perception of the surrounding reality. By contrast, Carla F. von Weizsäcker perceives information as the signal content that makes sense to the recipient.

The quality of information is therefore understood by reference to its content in certain conceptual categories such as: truth, timelines, relevance or usability. Qualitative concepts, by emphasising the semantic-pragmatic tendency, are widely used in social sciences with a particular emphasis on communication science. The precursors of mathematical information theory also fall within this trend. They are Norbert Wiener, Claude Shannon and Warren, to name but a few. Thanks to Wiener's work on cybernetic theories and the complementary theories of C. Shannon who cooperated with Weaver in 1949, a mathematical model of signal transmission was created (Garcia de Torres, 2001, p. 103 ) - to date being the core concept of the science of communication.

Russian philosopher Arkadij D. Ursul (1971) defines information as a reflection (mapping) of the diversity that characterises the surrounding reality (object, event, process, phenomenon). Such a variety in biology can be a set of signals reaching a living organism, whereas in psychology, stimuli received from the external human environment. Other specialists express similar opinions: R. Hartley - a mathematician, a slightly older colleague of another well-known mathematician C. Shannon, stated that information is a very capacious term and proposed to treat information "physically" and not through psychological interpretation. According to R. Ashby (1957), an expert in cybernetics, the concept of information is associated with the diversity of the surrounding world. N. Wiener (1954), an American mathematician and pioneer of cybernetics, treats information as an appellation deriving from a content taken from the outside world in the process of the adaptation of our senses to a piece of information.

A closer analysis of the quoted statements does not give any grounds either for rejecting any of them or for accepting any other concepts as the only correct ones. It can be admitted, however, that these are complementary opinions describing information from different points of view and in different contexts. Therefore, none of them can be treated as a comprehensive interpretation of this concept. It can be compared to a road seen by drivers in the fog: everyone sees only a small part of it. It is also worth mentioning L. Ciborowski's monograph The Information Fight, where he states that "the stimuli affecting the human reception system invoke a mental object in his or her imagination, reflecting the image of a material or abstract entity (subject, process, phenomenon, concept, etc.), which in his or her opinion (consciousness) is, to a certain extent, associated with these stimuli. 
This means that information is only those experiences that inspire the human mind to a certain imagination. Its existence is relatively related to the existence of man and his mind" (Ciborowski, 1999, p. 185).

It is to be admitted that the explanation of the holistic approach to the essential features of the subject of the study, referred to by the term information, is rather difficult. Neither Claude Shannon, the creator of the quantitative information theory, nor Stafford Beer, the author of one of the first scholarly articles on the use of cybernetics and the general theory of control in management in economic systems, had never defined the term, although they often used it in their arguments. Currently many authors are trying to fill this semantic gap, but there is no agreement about this as yet in the formulated views. This can be perceived in the functioning lexical norms as well as in the literature on the subject.

In the context of the subject discussed, it is a fundamental statement that information is a knowledge generating tool but - and this should be emphasised - not knowledge per se. Information is time related, it may be up-to-date or not. So it has product features and can be sold and bought. Knowledge, however, belongs only to a particular person. In the knowledge society, everyone should be able to navigate freely through waves of information and make its own interpretations. Freedom of movement is connected to freedom of expression and is about developing critical thinking skills to distinguish between useful and worthless information.

We humans are social beings voluntarily seeking contacts with other people and forced by reality to interact with other people. In these contacts it is information which becomes an indispensable binder of individual entities with their surroundings. This is expressed in the integrative function of information. Family relationships are an eloquent example of this role of information: conversations (and thus information exchange) is an indispensable factor integrating family members.

It is to be recognised that information should also be sought in the areas where it is used. Emphasis can be placed on the role of information in decision-making processes, as it is the case in business operations. However, a human being is a personality that needs to be considered in various dimensions - professional, social, psychological, cultural or historical. In each dimension, one always needs information to play a variety of roles.

Information, as a kind of "soft power", is a tool for shaping human personality. The reception of information forces each of us to analyse it and stimulates an appropriate response: it forces us to choose the purpose of the action and how to achieve it, especially when it is presented in an attractive and suggestive form. Each of us applies various criteria for such assessment: the criterion of usefulness, utility, profitability, moral criteria and others can be applied. Then follows an act of evaluating information. A frequent repetition of this sort of act creates the habit of taking action in accordance to specific evaluation criteria. Our consciousness formulated appropriately to specific principles and norms of behaviour that shape our personality comes into fray. This is especially relevant with regard to young people. Respectively, it is information itself which becomes an instrument of human education despite the fact that there could be diverse categories of recipients of information. As stated by Targowski, the governing power is not the one who rules but the one who has the right bits of information in the right memory available at the right time (Stefanowicz, 2009, p. 279). 
Individuals' rights to exercise freedom of choice is one of the main principles of liberal democracies. These rights are truly valuable when they are excercised by individuals through rational means. In turn, they can be amplified by the rights to reliable information and freedom of expression. This is why information per se should be considered a determinant shaping modern democracies.

Information shaping the social context plays an important role in shaping society. Information is not just a force affecting the external environment but also a subject of influence. The definitions belonging to this trend refer to a very wide range of phenomena and also to processes whose essence is relying on information that is important in creating social reality (Braman, 1989, p. 233). The condition for the development of the democratic community is free access to reliable information enabling the citizen to control the course of events and express his/her opinions (provide information). It is taken for granted that every citizen's opinion counts (at least theoretically) in the countries of liberal democracy. It is society that decides who will belong to the political elite. All citizens, through participation in elections, influence the shaping of forces in the Parliament. So as to implement these assumptions, genuine information, not fake information, is necessary to help citizens to make conscious election decisions. It is believed the reliable information gives people a chance to express their real opinion on a given political issue.

\section{The influence of information on shaping social attitudes}

The development of computer technology has caused an insatiable need for information, whose resource in cyberspace seems infinite. At the same time this situation causes an abstract temptation to control information, a temptation which, in fact, cannot be satisfied (Bauman, 2018, p. 55). Information as a force shaping society plays an important role in creating a social context. Information is not only a force affecting the external environment but also a subject of influence. The definitions pertaining to this trend refer to a wide range of phenomena and processes, including those which predominantly depend on conveying information, an important tool for creating social reality..

In the course of the discussion presented in the article, various dimensions of information were revealed. Firstly, the communication dimension - information can be transferred (communication is probably the most common activity performed with information). Secondly, the cognitive dimension - information can enrich one's knowledge (although it is not the only purpose). Third, the physical dimension - every piece of information is conveyed through some physical medium. The structural dimension is yet another one - each piece of information has a unique structure; perhaps every structure is information.

The role of information as a "spotlight" illuminating a particular situation is expressed in the theorem emphasised by specialists. It is claimed that each of our actions is preceded by making a specific decision. This applies to human participation in public and economic activities as well as in private life. The essence of decision making is or rather should actually be based on informed choices. It is a process that resembles moving in an unknown terrain. To reach the goal (to solve the problem), one must examine the paths that lead to 
it. Without knowing appropriate paths, moving forward will generally be at risk of failure. To avoid it, one must "see" the problem space, which requires an analysis and decision making - you need to have the right information to "illuminate" your surroundings. The more accurately this information describes reality, the more it will reduce the uncertainty concerning the effects of actions taken, and will protect a person against possible errors.

The decision function means that information is an indispensable element of the decision-making process (both in terms of the decision problem and the procedures used). Therefore, some people argue that the decision itself is one form of information, because it often affects its content.

The opinion forming function appears when information helps people in shaping an individuals' worldview as well as the views of other people who follow the advice of their peers or associates. Thereby, they build and hierarchise their own personal system of values (Stefanowicz, 2009).

The controlling function is related to the fact that the sender of information, as a result of its transmission, wants to get a specific response from the recipient and influence his or her behaviour, opinions or position. This function is also associated with the decision-making process, because an entity acquiring information from the external environment faces a decision dilemma at a later stage prior to undertaking specific actions. The motivational function, which is performed in connection with providing feedback to a person about the direction of its action, can additionally serve as an incentive to intensify efforts.

The human being constantly feels the need to receive new messages. The opinionforming function of information is clearly revealed when a person readily uses information made available by easily available sources: the Internet, social media, press, radio and television. This means that the recipient naturally limits his or her knowledge of the world to information published by these sources. In this way one is involuntarily submitting oneself to information manipulation: one pays attention to facts that can be learned from a given source and often remains unaware of the facts that this particular source omits. The mere fact that certain facts are selectively disclosed to the general public as "key information" (an expression heard often on television and radio) draws the recipient's attention to specific aspects of public life and diverts his or her attention from other manifestations, no less and perhaps more important, but intentionally silenced.

Properly profiled information affects the attitude of a person, the actions and decisions taken. It is owing to information captured in the form of a word, image or film (or any other form) that one can penetrate and influence another person's mind. As a consequence, the image of the recipient's world is shaped to a certain degree and his views are suggested. No surgery can penetrate the mind of another person to such an extent as information can. Such surgical treatments can only change the structure of the brain, which is not equal to changing the thought processes of the individual, his or her criteria for the assessments of reality and preferred values or attitudes. Information as a "soft power" is used to control the environment - to guide other people in the direction desired by a decision-maker. This is the foundation strategy for educating or rather shaping the minds of the young generation. Commercials which are based on the "soft power" of information provide a good instance of this strategy. Its purpose is not to provide pure 
information about specific products or objects, but it is aimed at convincing potential customers to buy them. This is sometimes done without any hesitation to use social engineering tricks, dishonest though they may be. The effects of such actions are both positive and negative. An example of the latter is the advertisement of tobacco products or alcoholic beverages often perversely presented as a desire to inform potential customers about specific articles available on the market. They also constitute information carrying a negative (aggressive, chauvinistic, homophobic, vulgar) content.

The impact of information as a "soft power" is conspicuous in shaping the information society and so are tasks which arise from the development of information technologies and constitute a challenge for information services in new conditions. But it is not the development of new technologies themselves that has such a revolutionary impact on society. The effect achieved is the effect of the synergy of two interconnected components: information and modern technologies to collect, process and spread it.

\section{The fake news phenomenon}

The so called post-truth era in the world of social media domination seems to have difficulties in verifying information. Even though it cannot always be verified, it does not mean it is away from the truth as such. It seems to be more difficult to reach it than it used to be but it is not impossible. Actually, it is the truth in spe in which the quality criterion of the received content is beginning to be appreciated. This is why it is important to understand the post-truth phenomenon - its basic tool, its specificity, the most important features and the way it can be influenced. This tool is fake news. The term has its place in the discussion of both phenomena of post-truth and the value of information or the condition of modern media at all. In the new media era we got used to being surrounded by the flow of information. Thousands of pieces of information that reach us through various channels of everyday life are nothing extraordinary. The appropriate classification of information becomes the real challenge, and widespread ignorance of how to separate false information from true information further aggravates this phenomenon. The classification and attitude towards information is governed by mathematical algorithms which, instead of us, have begun to select the messages we receive. At the same time a large proportion of society is unaware of this fact. The flow of information also includes those pieces of information that we call fake news. It is intentionally created for disinformation, entertainment or any other purpose. Its frequently shocking content reaches thousands of recipients on a daily basis. The increase in the popularity of news (including fake news) in the social media dimension is a phenomenon of the last few years. The dissemination of sensational fake news content is still a considerable problem in the mass media and internet users are outdoing each other in creating more and more absurd information.

Fake news is neither the truth nor a lie, because, although it is based on misinformation, it often contains partly true information. Fake news is created and used in situations where the purpose of a medial publication is not its correspondence with the facts but getting as much interest in the topic as possible (Gillin, 2017). Fake news is sometimes constructed to deliberately mislead the recipient so as to achieve, for instance, financial, 
political or even propaganda benefits. The creation of fake news is indeed intentional. Intentionality is the key to creating fake news, because the distribution of false contents is deliberately carried out for a specific purpose defined by the sender using channels that spread and speed up this distribution and expand the number of recipients of the specific contents. The reason why the Internet is such a readily used medium for spreading fake news is that it is often impossible to reach the real source of primary information (Gans, 2004 p. 39).

Analysing the phenomenon of fake news, which is a tool of the post-truth era, seems important primarily due to the fact that its presence in the media and public discourse has significantly increased. In 2017, the word went to the Merriam-Webster dictionary published since 1828 (Lekach, 2017, p. 41), and in 2018, the phenomenon of fake news aroused extremely high interest among internet users. It is apparent that fake news is overwhelming in the mass media and on the Internet (Ziółkowska, 2020).

Donald A. Barclay defines fake news as a propaganda tool, while Brian McNair goes much farther and notices the reason for the emergence of contemporary social and political trends in this phenomenon. Moreover, Monther Aldwairi and Ali Alwahedi claim that fake news was created as part of the psychological war (McNair, 2018). Several classifications of fake news can be identified, among which the most popular but also the most extensive one is based on the content criterion as presented in Claire Wardle's classification. $\mathrm{He}$ has enumerated the characteristics of seven types of false information: satire or parody, false connection, misleading content, false context, imposter content, manipulated content and fabricated content.

Some scholars argue that fake news is a response to the needs of recipients. We have to admit that due to the dynamic of fake news' spread we can clearly distinguish its presence in the media ecosystem. In accordance to the post-truth definition, fake news rely on objective facts which exert less influence on shaping the public, at the same time appealing strongly to human emotions and personal beliefs. So there will be messages that use the emotion or anecdotal arguments as the main persuasive device, and these messages will certainly be perceived as true ones. This information will effectively influence the public opinion by spreading doubts, mockery, hatred, or by the attempted creation of certain needs. The objective facts, the knowledge of reality and its description play a secondary role in the interpretation of fake news, which do not need to have much to do with the truth itself (Kucharski, 2018, p. 47). Considering Harold Laswell's model of communication, it is conspicuous that the post-truth, which applies in particular to the content that the recipient receives, goes together with a complete marginalisation of his or her own person and his or her ability to critically analyse the information received. The expected effect of fake news can be compared to the effects of the persuasion act. The ability to receive specific information, in turn, affects the scale of information-related impact on the recipient of the content (Palczewski, 2020, p. 154). At the same time, referring to objective facts does not necessarily change the mode of thinking about the world. Other people's arguments or opinions will always lose with a well-grounded belief arising from the core system of values and the accepted perception of the surrounding reality.

The fake news phenomenon is the result of many factors, e.g.: civilizational, cultural, economic and social. Sometimes the fake news phenomenon is identified with the crisis of 
journalism and the relativisation of the concept of truth. Tabloidisation or so called softening of news of the mass media comes to the fore when discussing the reasons for the creation and development of the phenomenon of fake news. False information is intentionally created to be attractive, sensational, appealing to recipients, satisfying their curiosity and at the same time diverting their attention from understanding the falsehood of the content they decode. Economic reasons are also of great importance. Fake news are produced by cheaper and faster means than news based on reliable sources of information. It also brings more profit to the people or media that create or distribute it (Palczewski, 2018, p. 157). For those who are aiming at destabilisation of a particular country, the use of fake news as a weapon is far more cheaper than any military action. (Chlebowski, 2019, p. 169) regrets that it is now possible to publish unconfirmed information as well as forward unofficial contents (without informing the recipient) or just duplicate messages from social platforms. Taking into account the disappearance of critical thinking and considering the fact that there is no one, objective truth, it should not surprise us that fake messages are gaining in status and popularity.

The technological factor has made fake news even more widespread while creating new areas that have enabled faster distribution of fake information. For some people this situation provides new opportunities to become a "media personality", which has urged them to take immediate steps at the medial level (Palczewski, 2018, p. 159). Fake news should be perceived as misinformation which is neither the truth nor a lie but manipulation. When explaining fake news, it is worth noting the statement of the EU Commissioner for Security Sir Julian King who stated that "false information and misinformation have become a weapon, which is a serious threat to countries' stability and security. The use of trusted channels to disseminate harmful and divisive content requires a clear response which should be based on greater transparency, traceability and responsibility" (EC, 2018a).

It is worth emphasising the Eurobarometer survey, according to which $83 \%$ of the respondents said that false information is a threat to democracy. They express concern that misinformation aims at influencing elections and immigration policy. The study also highlights the importance of high-quality media. Respondents perceive traditional media as the most reliable source of information (radio 70\%, television 66\%, printed press 63\%). Internet information sources and online video services were found to be the least reliable with a trust level of $26 \%$ and $27 \%$ respectively (EC, 2018b).

In addition, the European Commission's Joint Research Centre has published a study (EC, 2018c) on false information and misinformation in which it is pointed out that twothirds of online news readers prefer to access them via algorithm-based platforms such as search engines, news applications, and social networking sites. It has been found that market power and income sources had shifted from news publishers to platform operators, who have an immeasurable amount of data from which they have to appropriately match readers with the articles and advertisements addressed to them. So, as it has already been mentioned, the more dangerous this phenomenon is, the more vulnerable the recipient is to the influence of fake news. To sum up, fake news is the main tool of the post-truth era and is defined as misinformation deliberately misleading the recipient to achieve the goals set by the sender. Intentionality is the key to describing this phenomenon. 


\section{The influence of misinformation on consolidated democracies}

Until now the phenomenon of post-truth has been referred to politics. It is gradually covering other domains of social life. We have witnessed the rise of the circumstances in which real facts are not the most important value in shaping public opinion. It affects feelings or influences beliefs, thus plays a key role in moulding public opinion. Truthfulness has ceased to be crucial. Words and discourse in the public space live more and more their own lives and the sense of the phenomena they describe is distorted or the context of their origin disappears.

The system of consolidated democracies is liberal democracy with its democratic rule of law (Kozłowski, 2019/2020). Depending on the degree of freedom and the level of its restrictions, the different political systems can be divided into the following categories: consolidated democracy, semi-consolidated democracy, hybrid regime, semi-consolidated authoritarian regime, and, in the most extreme cases, consolidated authoritarian regime. ${ }^{1}$ According to the authors, formulating an assumption about the impact of fake news as tools of misinformation on consolidated democracies requires describing the impact of information on shaping society. It should be recognised that information with its impact through the content of human sensory and mental experiences represents an enormous strength and value in shaping the functioning of democracy.

The human inclination to cheat other people has now been strengthened with new opportunities of expression ensuing from civilisational and technological advancement, with general tolerance for such a behaviour being increased. Even though ethics and morality are still dominant in public discourse, at least on the level of declarations, they do not always realise in practice. Allowing half-truths or manipulations to increase the importance of feelings in perceiving the world contributes to far-reaching changes in social structures. People-to-people contacts, attitudes towards authorities and trust in the media are being re-evaluated in a way leading towards an alternative reality in which there are no clear laws systematising the perception of reality.

The authors of the article indicate that it is extremely important to create a secure public space in the sense of freedom from harmful manipulations to ensure the development of democracy. The basic condition for a rational action in all spheres of human existence is always the need to make accurate decisions, which is inextricably linked to the need for relevant, objective and truthful information. This condition indicates that each piece of

\footnotetext{
This article adopts a typology of political systems based on their attitude to the concepts of democracy and authoritarianism, as proposed by Andrzej Antoszewski and Ryszard Herbut, who in turn draw on the conceptions put forward by scholars such as Larry Diamond, Joseph Schumpeter and Robert Dahl. Antoszewski and Herbut emphasise the need to distinguish two sub-categories of democratic systems: consolidated (stable-full) and semiconsolidated (unstable-flawed/limited). Consolidated democracies are those that respect the separation of powers, sustain competitive party systems and adequately competitive elections, do not include decision-making centres uncontrolled by voters, impose limits on executive authority, and guarantee civil rights, as reflected in the unfettered development of civil society. Semi-consolidated democracies are often "new", or, as Dahl calls them, "newer" or "immature"; Diamond describes them as "electoral democracies". Although they meet the basic criteria characteristic of consolidated democracies, there are nevertheless flaws in their practical application. Consequently, such democracies must be considered incomplete (Antoszewski \& Herbut, 2001, pp. 18-49).
} 
information has its price proportional to the value of decisions manifested efficiently through the prism of the accuracy of the cost selection.

To act efficiently and effectively in all spheres of human existence, one must first get to know the areas and materials of the operational fields. This entails obtaining information about what, where, and when should be done to achieve the desired states and effects. Reliable and comprehensive information about this is a prerequisite for the selection of appropriate instruments, operators and variants of action (Ciborowski, 2010), which represents an enormous strength and value in shaping both positive and negative consequences in all spheres of human existence.

Living and acting in the modern world means the appropriate use of information. This statement consolidates the sense of social, economic, political and educational transformations. A person involved in various social processes and playing specific social roles from the earliest moments of his or her life is subject to a stream of diverse information (Goban-Klas \& Sienkiewicz, 1999, p. 179).

In human society, everyone should be able to move freely through waves of information. Freedom of movement is about developing critical thinking skills to distinguish between useful and worthless information. We receive more and more information and experience it more and more intensively; we, as citizens, are increasingly becoming the object of manipulation understood as actions aimed at convincing us to adopt a specific behaviour.

The fundamental factors constituting the current reality are the flow of information, the intensified pace of life and the growing number of changes (Ball, 2000). However, the excess of information forces the recipient to intensify the effort put into the reception and selection of information. Therefore, the information management skills have become crucial. The increasing amount of information should serve the development of the economy, contribute to strengthening democracy or improving the quality of social life. However, the currently observed excess of information can overwhelm the recipient and cause problems with filtering the information. This is, in turn, conducive to the formation of information noise, which is becoming increasingly widespread nowadays. Separating facts from opinions and truth from falsehood becomes a challenge that the contemporary consumer of media contents faces on a daily basis. In such an environment it is extremely easy for fake news to function. The aforementioned phenomena do not contribute to the general development. Nevertheless, one can venture a claim that reliable and comprehensive information, which are a prerequisite for choosing the right instruments as well as options, should be available to the citizen.

\section{Conclusions}

Contemporary societies cannot be diagnosed as having a passive attitude to the changing social reality. The authors believe that ongoing discussions around the post-truth issues and the problems of the increasing amount of fake news force actions that aim at limiting their pervasiveness. Such activities are undertaken by several institutions like the European Union, the media or NGOs. Admittedly, online platforms play an important role in 
combating the misuse of their infrastructure by hostile entities and strive to ensure the safety of their users and the public. Appropriate control and preventive activities are undertaken by Buzzfeed websites dealing with the investigation and verification of false news from a journalistic perspective or an initiative of the International Federation of Library Associations and Institutions (IFLA), which has prepared and published a short guide on how to verify information to guard against fake news. There is a special Polish portal, the Konkret24408, whose editors deal with analysing information and detecting fake messages. In thematically segregated sections one can find popular news about politics, health or science which has been verified and properly marked as true or false. Another similar portal, acting under the name of Antyfake, is a non-governmental organisation that carries out its mission on the Facebook platform.

Preventive actions in this area will bring greater social benefits than just post factum initiatives. Such actions are also concerned with decreasing the amount of fake news the general public is fed with. Preventing here cannot mean political censorship, but is related rather to checking and verifying information and educational practice. The call for rational thinking comes to the fore and precludes the non-reflective reception of media content. The increasing awareness in this area may result in the general public (the recipients of media content) being more reflective and analytical as regards the nature of the information received. Such awareness, in the context of publishing activities explaining this phenomenon, may influence the citizens' ability to think critically and the will to check the sources or authors of various publications and programmes. In addition, reading the texts and viewing the entire content, instead of a brief glance at the headline, will allow news recipients to familiarise themselves with the topics properly. Beyond doubt, this ability cannot be acquired when one ignores the complexity of society. In reality, it requires support of social education and an active warning about the harm brought about by fake news. This must be conducted at a similar level as we fight addiction to nicotine, alcohol, drugs or road rage. Activities that increase awareness of fake news can effectively prevent the spread of misinformation. If the recipient, who, as an active participant in the information society, also becomes a sender, will think twice before sharing fake news with others, there is a chance that false information will not become popular and will not gain followers and resenders. That is why it is so important to educate the general public about the destructive impact of fake news. This should not be just a small CSR project. This should be a highly supported and promoted action financed by supranational organisations free of governments and political control to protect them from intentional and possibly destructive political influence.

The recipient of media contents should know that his actions each day affect larger social groups. By clicking on the sensational publication, one satisfies his or her curiosity, but also brings profits to media owners and their associates and employees. The actions of these media owners are often far from ethical activities and are focused on bringing political or financial benefits to certain political and medial circles or are intended to cause disorder by impairing social integration. The one who passes a particular harmful or dishonest publication on without further checking it will only strengthen the impact of its derogative, offensive or manipulative content. It is as simple as that. Thus, education and public discussion are a basis for effective prevention of disinformation in this context. Such 
a conscious and active approach of the recipient may result not only in raising the level of the published content but also in increasing the citizens' knowledge of information in the future.

\section{References}

Antoszewski, A., \& Herbut, R. (2001). Systemy polityczne współczesnego świata [Political Systems of the Contemporary World]. Arche.

Ashby, W. R. (1957). An Introduction to Cybernetics [Scientific Information as part of the Management Process]. Chapman and Hall LTD.

Babik, W. (2008). Informacja naukowa jako przedmiot zarządzania [Managing Information in Science]. In Pietruch, D., \& Reizes, W. (Ed.), Zarządzanie informacją w nauce. Uniwersytet Śląski, Katowice.

Ball, R. (2000). The scientific information environment in the next millennium. Library Management, 21(1). https://doi.org/10.1108/01435120010305582

Bauman, Z. (2018). Liquid Modernity. Polity Press.

Braman, S. (1989). Defining information: An approach for policy-makers. Telecommunication Policy, 13(3), pp. 233-242. https://doi.org/10.1016/0308-5961(89)90006-2

Ciborowski L. (1999). Walka informacyjna [Information Struggle]. Toruń.

Ciborowski L. (2010). Pojęciowa Interpretacja Terminu „Informacja” i jej pochodnych [Conceptual Interpretation of the term "Information" and its Derivatives]. Zeszyty Naukowe AON, 81(4).

EC (2018a). Dezinformacja uderza w demokrację [Disinformation Hits Democracy]. European Commission. https://ec.europa.eu/poland/news/180426_fake_news_pl.

EC (2018b). Zwalczanie dezinformacji w internecie: Komisja proponuje ogólnounijny kodeks postępowania [Combating Disinformation on the Internet: The Commission proposes an EU wide code of procedure]. European Commission. https://ec.europa.eu/commission/presscorner/detail/pl/IP_18_3370

EC (2018c). The digital transformation of news media and the rise of online disinformation. European Commission. https://ec.europa.eu/jrc/en/news/digital-transformation-news-media-and-rise-fake-news.

Fischer, B., \& Świerczyńska-Głownia, W. (2006). Dostęp do informacji ustawowo chronionych, zarządzanie informacją. Zagadnienia podstawowe dla dziennikarzy [Access to Legally Protected Information, the Management of Information. Basic Issues for Journalists]. Palo Alto School. Wyd. UJ, Kraków.

Gans, H. (2004). Deciding what's news: a study of CBS Evening News. NBC Nightly News, Newsweek and Time. Northwestern University Press.

Garcia de Torres, E. (2001). Szkoła PaloAlto [PaloAlto School]. In Dobek-Ostrowska, B. (Ed.), Nauka o komunikowaniu. Podstawowe orientacje teoretyczne [Communication Science. Basic Theoretical Premises]. Uniwersytet Wrocławski.

Gillin, J. (2017). Fact-checking fake news reveals how hard it is to kill pervasive "nasty weed" online. Politifact. www.politifact.com/punditfact/article/2017/jan/27/fact-checking-fake-news-reveals-how-hard-it-kill-p/

Goban-Klas, T., \& Sienkiewicz, P. (1999). Społeczeństwo informacyjne: Szanse, zagrożenia, wyzwania [Information Society: Opportunities, Threats, Challenges]. Wydawnictwo Fundacji Postępu Telekomunikacji Kraków.

Greniewski, H. (1967). Cybernetyka niematematyczna [Non-Mathematical Cybernetics].Wyd. PWE, Warszawa. Groniewska, H. (1990). Koordynacja systemu zasilania w informacji. Przegląd Organizacji 11.

Chlebowski, M. (2019). Dziennikarze polscy wobec teorii społecznej odpowiedzialności prasy (badanie ilościowe) [Polish Journalists Faced with a Theory of Social Responsibility of the Press (Quantitative Study)]. Kultura popularna [Popular Culture] 59(1).

Kozłowski, A. R. (2019/2020). Populism as a Factor of Destabilisation in Consolidated Democracies. The NISPAcee Journal of Public Administration and Policy, 12(2), Winter 2019/2020, pp. 81-108. https:// doi.org/10.2478/nispa-2019-0015 
Kucharski, J. (2018). Postprawda - próba dookreślenia znaczenia [Post-Truth - An attempt at Making the Meaning More Precise]. In Grabowski, T., Lakomy, M., Oświecimski, K., \& Pohl, A. (Eds.), Postprawda. Spojrzenie krytyczne [Post-Truth - A Critical View]. Wydawnictwo Naukowe Akademii Ignatianum w Krakowie.

Lekach, S. (2017). 'Fake news' and 'false flag' are being added to dictionary.com, because 2017. Mashable. https:// mashable.com/2017/09/28/fake-news-politics-dictionary/?europe=true

McNair, B. (2018). Fake News, Falsehood, Fabrication and Fantasy in Journalism. New York, Routledge.

Palczewski, M. (2018). Świat fake newsa. Sily sprawcze i konsekwencje [The World of Fake News. The Determining Forces and Consequences]. Tomasz, W. G., Lakomy, M., \& Konrad, O. (Eds.), Bezpieczeństwo informacyjne $\mathrm{w}$ dobie postprawdy [Information Security in the Post-Truth Era] (pp. 155-168). Wydawnictwo Naukowe Akademii Ignatianium w Krakowie.

Palczewski, M. (2020). Postprawda -co to jest? [Post-truth - What is it?] www.sdp.pl/felietony/14297,postprawdaco-to-jest-, 1497430864,

Stefanowicz, B. (2009). Społeczne funkcje informacji [The Social Functions of Information]. Zeszyty Naukowe Uniwersytetu Szczecińskiego [Scientific Periodicals of Szczecin University].

Ursul, A. D. (1971). Informacija. Nauka [Information. Science]. Moscow.

Wiener, N. (1954). Cybernetics or Control and Communication in the Animal and the Machine. The M.I.T. Press and John Wiley \& Sons, Inc. https://doi.org/10.7551/mitpress/11810.001.0001

Ziółkowska, M. (2020). Internet opanowany przez fake newsy [The Internet in Control of Fake News]. http:// dziennikarstwo.wroclaw.pl/internet-opanowanyfake-newsy

Ziółkowski, R. (2007). Zarządzanie informacją w regionie turystycznym [The Management of Information in the Tourist Region]. Wyd. Politechnika Białostocka. 